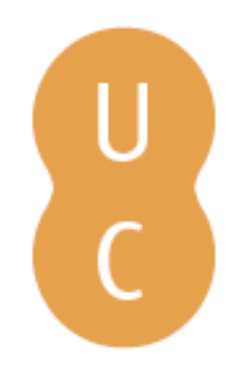

\title{
pompalina
}

\section{Garrett, Balzac e a costureirinha chinesa}

Autor(es): $\quad$ Borralho, Maria Luísa Malato

Publicado por: Imprensa da Universidade de Coimbra

URL

persistente: URI:http://hdl.handle.net/10316.2/38702

DOI: $\quad$ DOI:http://dx.doi.org/10.14195/978-989-26-1164-8_25

Accessed : $\quad$ 26-Apr-2023 12:50:46

A navegação consulta e descarregamento dos títulos inseridos nas Bibliotecas Digitais UC Digitalis, UC Pombalina e UC Impactum, pressupõem a aceitação plena e sem reservas dos Termos e Condições de Uso destas Bibliotecas Digitais, disponíveis em https://digitalis.uc.pt/pt-pt/termos.

Conforme exposto nos referidos Termos e Condições de Uso, o descarregamento de títulos de acesso restrito requer uma licença válida de autorização devendo o utilizador aceder ao(s) documento(s) a partir de um endereço de IP da instituição detentora da supramencionada licença.

Ao utilizador é apenas permitido o descarregamento para uso pessoal, pelo que o emprego do(s) título(s) descarregado(s) para outro fim, designadamente comercial, carece de autorização do respetivo autor ou editor da obra.

Na medida em que todas as obras da UC Digitalis se encontram protegidas pelo Código do Direito de Autor e Direitos Conexos e demais legislação aplicável, toda a cópia, parcial ou total, deste documento, nos casos em que é legalmente admitida, deverá conter ou fazer-se acompanhar por este aviso.

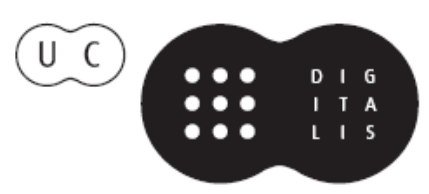


Maria Luísa Malato Borralho

Universidade do Porto ${ }^{1}$

\section{GARRETT, BALZAC \\ E A COSTUREIRINHA CHINESA}

A Ofélia Paiva Monteiro, a Professora que eu queria ser, não fosse cada um de nós inevitável paráfrase de si.

"Le chef du village, un homme de cinquante ans, était assis en tailleur au milieu de la pièce..." (Sijie, 2000: 9). Curioso este "assis en tailleur», na primeira linha do livro, como se ele fosse já o prenúncio do enredo de Balzac et la Petite Tailleuse Chinoise, um romance de Dai Sijie. A posição "de alfaiate" lembra já a posição da mais antiga representação do escriba, que conta(biliza) entre o pavimento e o corpo. E todavia, este chefe da aldeia parece encarnar a instituição: suspeita de livros, estão proibidos, e pergunta a si próprio qual a classificação que deve dar a um violino... Mas não. Para falarmos do enredo talvez eu comece mais tarde, indo a história já a meio. Pensar é apenas cruzar imagens e palavras, entrecortar histórias como se entrecortam livros. Na verdade, todas as histórias começam in media res, no meio de outra, como se as recolhêssemos da interminável trama de Xerazade. Já a meio: no momento em que Ma abre um livro de Balzac, e descobre o mundo de Ursule Mirouët: "Brusquement, comme

\footnotetext{
1 Este ensaio foi elaborado no âmbito do Projeto "Interidentidades" do Instituto de Literatura Comparada Margarida Losa da Faculdade de Letras da Universidade do Porto, Unidade I\&D financiada pela Fundação para a Ciência e Tecnologia, integrada no Programa Operacional Ciência e Inovação 2010 (POCI 2010), do Quadro Comunitário de Apoio III (POCI 2010-SFA-18-500).
} 
un intrus, ce petit livre me parlait de l'éveil du désir, des élans, des pulsions, de l'amour, de toutes ces choses sur lesquelles le monde était, pour moi, jusqu'alors demeuré muet" (Sijie, 2000: 72). Falemos pois do momento em que descobrimos num livro, ou em alguém que nos lê um livro, a grandeza do mundo e das suas vozes. Talvez até somente daquele raro momento em que o podemos partilhar, fazendo ver aos outros a beleza de o reconhecermos. Hesitantes ainda, como se de uma tarefa impossível se tratasse: “- Vas-y, m'encouragea-t-il. Raconte-nous quelque chose que je ne connais pas encore. J'acceptai, un peu hésitant, de jouer le rôle du conteur de minuit» (Sijie, 2000: 153).

Balzac et la Petite Tailleuse Chinoise passa-se numa remota aldeia da China dos anos 70, no século passado. O contexto é o de uma Revolução Cultural, levada a cabo entre 1965 e 1976: "les dates varient véritablement selon la place accordée à Mao lors de cette "révolution" (Plaquette, 2008: 9). O livro descreve uma cultura em que os livros se encontram banidos, da contrarrevolução que é o amor ao livro, o poder desse livro. Há certamente um contexto político "orquestrado". Escrito em francês por um chinês no exílio, o livro, de 2000, será traduzido para mandarim em 2003, como demonstração da política de abertura da China ao Ocidente, ainda que com um posfácio do tradutor em que este afirma discordar do valor que nele é dado à literatura francesa. Em contraponto, Bernard Pivot, logo na emissão de 21 de Janeiro de 2000 do "Bouillon de Culture", promove-o com todas as armas suicidas de um resistente "de maquis": "si ce livre ne devient pas un best-seller, alors cette emission ne sert à rien!" (cf. Plaquette, 2008: 19). Interessa certamente falar sobre o contexto de um livro enquanto objeto clandestino ou ignorado, queimado ou desprezado, desaproveitado...Há tantas formas de ler como formas de não ler, e todas elas são determinantes. Mas o que nos interessa aqui é antes de mais o livro sem forma ou tempo predefinidos, o livro que não quer saber da forma, aquele que sempre pode passar despercebido na citação de uma aula, numa intimidade noturna, no avesso de um colete de pele, nos versos de um eremita, nos moldes de um alfaiate, nas fórmulas de uma curandeira, nos mexericos das mulheres, no tricot de uma poetisa, nas profecias de um sonho, na toponímia de um lugar, nos sons de um violino... Aquele livro velho como o mundo no qual todos nós colocamos um verso, uma palavra ou um silêncio, o livro que vai das palavras 
de alguém para as nossas, antiquíssimos sons em novos timbres, caminhos tantas vezes percorridos que sempre levam a insuspeitados sentidos. O livro que ensinamos a alguém, como se dele dependesse a sobrevivência da espécie, não a espécie do corpo mas a espécie do espírito: “...le livre rêvé: une fois que vous l'aviez fini, ni votre sacrée vie ni votre sacré monde n'étaient plus les mêmes qu'avant" (Sijie, 2000: 137).

Porque ensinamos nós senão para falarmos difusamente desse livro? Que outro pretexto temos para substituir a beleza de um texto pela forma mais tosca do nosso? Porque escrevemos nós ainda? Porque escrevemos nós de novo, redizendo? Talvez porque a única forma de pagar a imensa dívida do que recebemos é passá-la a alguém. Ecoa ainda em mim a voz indómita de Chimène, ouvida pela primeira vez na aula de Literatura Francesa, em 1979: “- Va, je ne te hais point. - Tu le dois. - Je ne puis." (Corneille, 1976: 66). E o timbre quase só bastou para me ensinar a ver o muito que é dito no que não é dito. O timbre é subtil, e um bom pedagogo é cuidadoso: "Convirá nunca esquecer que uma experiência mal conduzida pode causar irreparáveis estragos numa personalidade em formação" (Barata: 1979: 47). Admiramos tal gentileza em fazer ver, e a fortaleza de quem o faz sem usar da força autoritária, militar. Exaltou-as Garrett:

Escreveu um filósofo romano que não havia espectáculo mais digno de Deus que o do varão forte lutando só e braço a braço com a adversidade. Outro conheço eu mais digno ainda da divindade e em que melhor se espelha sua imagem; é o do parente, do educador desvelado formando a alma tenra e o coração inocente de seu pupilo, moldando-os para a virtude e para a razão, e preparando-o para a felicidade (Garrett, 2009: 106-7).

É certamente esta suave generosidade que em grande parte nos faz compreender a fidelidade de Garrett ao "progressismo iluminista". "Iluminista" naquele sentido em que o dizia Alberto Ferreira: crente no poder da cultura, tanto nas luzes da razão como nas do sentimento, intelectual assumidamente social, que não pode ver no sentimento estético apenas um prazer individual e desinteressado (cf. Ferreira, s.d.: 41 et passim). É a "dívida”, ou a dádiva”, que o liga indelevelmente aos "parentes", aqueles quase pais, seus tios, João Carlos 
Leitão, Frei Alexandre da Sagrada Família, de quem tentou publicar a obra manuscrita (Monteiro, 1971: I, 45n): "Eu tive a boa fortuna de receber uma educação "portuguesa velha" [...] conquanto fosse mal aproveitada" (Garrett, 2009: 106). Deseja depois estendê-la aos leitores dos seus romances, aos espetadores do seu teatro, à audiência dos seus discursos, ainda quando teoriza um teatro moral, quando ficciona a visão coletiva do louco no Porto de Pireu, ou escreve sobre uma viagem de Lisboa a Santarém e a leitura do D. Quixote de Cervantes: "Ora nesta minha viagem Tejo-arriba está simbolizada a marcha do nosso progresso social: espero que o leitor entendesse agora. Tomarei cuidado de lho lembrar de vez em quando, porque receio muito que se esqueça” (Garrett, 2010: 101). Ainda quando escreve a sua filha: "Ganha a afeição de tuas superiores e mestres que são as verdadeiras mães que Deus te deixou"; "Não te esqueças nunca, minha filha, que os maus são sempre infelizes, ainda que o não pareçam. Adeus, estuda, teme a Deus, e adora a verdade, que enches teu pai de alegria e de gosto" (Garrett, s.d.: I, 1461-2)...

Se existem vetores que nos permitem estudar toda a obra de um autor, um dos possíveis em Garrett é precisamente o dessa "educação visual" não impositiva, que a todos vai "gradualmente dizendo e mostrando". Sobre as dívidas dos filhos aos pais: "Creio que ninguém vai imaginar daqui que um pai ou educador se deve pôr a fazer destes sermões a seus filhos ou pupilos. O como e o quando é a grande ciência do mentor" (Garrett, 2009: 111n). Isto viu-o Ofélia Paiva Monteiro muito cedo, e nós lhe devemos essa acuidade: estudar Garrett através do seu processo formativo (cf. Monteiro, 1971: I, IX-XII), analisar na sua obra as camadas críticas que iam do manuscrito ao impresso, promover a edição crítica (cf. Monteiro, 2006: 19 ss.), são formas de compreender nele o mecanismo fulcral, "os estratos que se amalgamaram no artista", o "itinerário íntimo". Tal compreensão, é certo, não exclui nunca a literariedade histórica, institucionalizada pela periodologia literária. Mas até essa devemos ler com atenção, isto é, atentando no seu dinamismo formativo, o que perceciona o "compromisso barroco-iluminista" (cf. Monteiro, 1962, passim), ou o iluminista-romântico (cf. Monteiro, 1971, passim). Dinamismo histórico que aliás não é só coletivo, mas acima de tudo individual, porque cabe ao indivíduo escolher influências, aproximar-se ou distanciar-se dos paradigmas da sua época. Ora, no caso de 
Garrett, não se pode perceber o formando sem antever nele o formador, meras variantes de uma repetida experiência de criação:

Quasi dos primeiros anos de razão comecei a reflectir sobre minha educação e a compará-la com a que via dar a outros; e senti sempre, não sei por que instinto, uma predilecção inexplicável por esta arte de formar homens, arte a mais sublime e útil de todas as deles, a que mais nos assemelha à Divindade, a que mais aproxima a criatura do Criador. (Garrett, 2009: 106)

Há certamente uma admiração, sine qua non, que vai do discípulo para o mestre, já que cabe ao discípulo escolher o mestre e raras vezes sucede o inverso. Mas ela necessita quase sempre de uma atenção recíproca do mestre para com o discípulo, de uma demiurgia amorosa, feita dessa virtude que é insuflar no outro uma nova vida, crendo que ficamos depois incólumes. Luo, personagem do romance de Dai Sijie, concebe-se como Pigmaleão (cf. Ovídio, Metamorfoses, X, 7). O seu amor pela Costureirinha animará Galateia, a mulher finalmente digna do seu amor, aquela com quem paritariamente poderá dialogar e falar de todos os livros, do livro:

- Elle n'est pas civilisée, du moins pas assez pour moi! (Sijie, 2000: 39)

- Je l'aurais lu, page par page, à la Petite Tailleuse. Cela l'aurait rendue plus raffinée, plus cultivée, j'en suis convaincu. (Sijie, 2000: 77)

- Avec ces livres, je vais transformer la Petite Tailleuse. Elle ne sera plus jamais une simple montagnarde (Sijie, 2000: 127).

Há também um propósito de Pigmaleão na obra de Garrett. Um gosto em pegar numa pedra em bruto, moldá-la e depois pedir-lhe para falar. Cremos que foi isso que também o atraiu nas mulheres que amou: Análias, Lílias, Júlias. Mas sobretudo na primeira mulher, Luísa Midosi, que pela primeira vez viu na representação da sua tragédia Catão, confundindo-a com a destinatária de uns versos do Prólogo: "E tu, sexo gentil, delícias, mimo,/ afago da existência e encanto dela...". Luísa Midosi, tão mais nova e inexperiente, ainda adolescente... Teófilo diz a família Midosi burguesa e materialista (Braga, 1903: 329). Talvez a família não fosse assim tão avessa às artes: tinha pelo menos hábitos cosmopolitas 
(Monteiro, 1971: I, 214-7). O mesmo parece ter sucedido com Luísa Midosi, que tanto ameaçou a estabilidade financeira de Garrett (Amorim, 1984, II, 207-211). Se a escritura pública da separação, assinada em Outubro de 1839, afirmava "a impossibilidade de fazerem vida em comum pela incompatibilidade absoluta de génios”, Garrett recriminará ainda a Luísa, numa carta de 1853, uma lição desaprendida: "Esqueces-te de tudo, tudo e tudo" (Amorim, 1884: II, 209). Para ela certamente escrevera, entre 1822 e 1823, o Liceu das Damas, com o subtítulo "Lições de Poesia a uma jovem Senhora". Encontra-se destinado a uma jovem, identificada ora pelo nome algo arcádico de "Lília" (mas não designara Garrett assim também Isabel Hewson, a soberba, nuns versos de juventude?...), ora por "Júlia" (será Júlia ainda a que representava a inveja, naquele mesmo poema de juventude sobre os sete pecados capitais?, ou a Júlia que reaparece nas Viagens?). Talvez o seu verdadeiro destinatário seja um eterno feminino. Estas lições não chegaram a ser publicadas na totalidade, e o próprio plano do manuscrito não chegou a ser concluído. "O que ficou dessa obra abordada conserva-se, em autógrafo assaz longo, no riquíssimo espólio garretiano pertencente à Biblioteca Geral da Universidade de Coimbra, onde constitui o complexo manuscrito 127, ainda hoje inédito em grande parte da sua extensão", mas já rigorosamente analisado por Ofélia Paiva Monteiro, sendo visíveis nele "os elementos que aduzem à perceção do deslizar que entre nós leva das Luzes aos primórdios românticos" (cf. Monteiro, 2011: 197 e 1971: I, 353). Garrett di-lo concebido à imagem das Lettres à Emilie sur la Mythologie, de Demoustier (que José Ferreira Borges tinha parcialmente adaptado ao gosto português, talvez mais do que simplesmente traduzido, em 1819). Dialoga também com o Emílio, de Rousseau. Mas é, na forma e nas intenções, um produto bem distinto destes, já que se centra sobretudo na organização de uma brevíssima História da Literatura. O que o torna também cativante é esta confusão entre as carícias amorosas e a aprendizagem da Literatura, "o sério engrinaldando co'as rosas do prazer", sendo o amor da beleza "natural sentimento do homem", até porque "o saber pesado e pomposo não se adequava à jovem Lília, nem ao professor e 'amante' que lhe fala, máscara textual de Garrett" (Monteiro, 2011: 200). Garrett deseja instruir e construir a mulher que ama (talvez Luísa, talvez outra). Sempre o fez, embora cada vez menos. O último vestígio de Pigmalião é certamente uma carta a Rosa Montufar (1846-1851): "Tinha desesperado de incontrar a mulher que Deus formara à minha similhança" 
(Garrett, 2007: 79)... Parece-nos igualmente muito significativo que, cerca de dez anos antes, quando Garrett conheceu a jovem Adelaide Deville, mãe de sua única filha sobrevivente, ele lhe envie um exemplar da Nova Heloísa, de Rousseau, levando a lápis umas notas suas, intencionais, que Adelaide comentaria (cf. Malpique, 1954: 179).

Entre renovados Abelardos e renovadas Heloísas, o livro sempre foi um ambíguo local de encontro (Steiner: 2005: 57). Uma mão poisada sobre outra, para nos guiar, como a de Virgílio sobre a de Dante, um livro sobre outro livro:

E poi che la sua mano a la mia puose/ com lieto volto, ond'io mi confortai,/ mi mise dentro a le secrete cose (Divina Commedia, Inferno, III, 19-21).

Uma mão poisada sobre a outra para nos perder, como a de Paolo sobre a de Francesca Rimini, um livro sobre outro livro:

Noi leggiavamo un giorno per diletto/ di Lancialotto come amor lo strinse;/ soli eravamo e sanza alcun sospetto./ Per più fiate li occhi ci sospinse/ quella lettura, e scolorocci il viso;/ ma solo un punto fu quel che ci vinse./ Quando leggemmo il disiato riso/ esser baciato da cotanto amante,/ questi, che mai da me non fia diviso,/ la bocca mi baciò tutto tremante./ Galeotto fu il libro e chi lo scrisse:/ quel giorno più non vi leggemmo avante (Divina Commedia, Inferno, V, 127-138).

Fazemos sempre o que devemos, que é afinal tudo o que podemos e o que queremos. O resultado é uma certa disciplina que supostamente liberta, porque nos permite atingir um determinado tipo de satisfação: o prazer do controlo da situação, próprio do demiurgo, em muito semelhante ao controlo do jogador ou do encenador, uma "estética da melancolia", até certo ponto, ainda que ironicamente, "l'art de vivre":

De la confusion identificatoire de soi-même et du regard maléfique, on accède à la contemplation de soi-même au sens de l'humour théâtral. Comme la mélodie musicale qui s'évanouit si la référence harmonique n'est là pour lui donner un 
registre, le travail des décors permet à l'art de vivre d'inaugurer l'apparence et de conforter une indépendance ludique (Lambotte, 1984: 153).

É preciso portanto imaginar Chimène feliz. E também Garrett. E Balzac. E Sijie. Garrett em criança, viveu umas férias de Verão refugiado "numa cabana de colmo, onde com os meus livros e os meus versos passei os mais felizes dias, conquanto os mais solitários, da minha vida. [...] Oh minha Cabana das ilhas, para que te deixei eu?" (apud Monteiro, 1971 \: I, 73n-74n). Raphael, em La Peau de Chagrin, de Balzac, compara as delícias da escrita às do amor, e ao contacto físico da água que escorre sobre o corpo, como se fora retorno edénico, ainda no ventre da mãe: "un divin plaisir", "le plaisir de nager dans un lac d'eau pure, au milieu des rochers, des bois, des fleurs, seul, caressé par une brise tiède..." (Balzac, 1831: 269). Luo guarda a mala de livros proibidos numa gruta quase inacessível, próxima da cascata em que se banha com a Costureirinha. E dirá depois a Costureirinha: "Les romans [de Balzac] que Luo me lisait me donnaient toujours envie de plonger dans l'eau fraîche du torrent" (Sijie, 2000: 178). A alegria pânica, "la jubilation verbale" de que fala a Arte Poética de Claudel (Jourdain, 1992: 103). A "Babel heureuse", de R. Barthes (1973: 10). Como se a palavra fosse o último elo ao Paraíso, como se a história dos outros fosse uma comum hipótese de salvação. Autores, leitores, todos eles Criaturas que se tornaram Criadores, quebrando sucessivamente o fio que denunciava a criação: vem, ouve-me, pensa, vai, vive, esquece-me. Dirá Chimène da sua honra, ao deixar partir Rodrigo: "elle éclate bien mieux en te laissant la vie/ Et je veux que la voix de la plus noire envie/ Elève au ciel ma gloire et plaigne mes ennuis/ Sachant que je t'adore et que je te poursuis" (Corneille, 1976: 66). Esse amor com que transmitimos, e através do qual encorajamos o outro a se libertar dos nossos compromissos, é afinal o que mais em nós se assemelha à Divindade, aquilo "em que melhor se espelha sua imagem" (Garrett, 2009: 106); "o poder de chamar à vida seres de ficção aproxima o romancista de Deus", afirmará depois mais desenvolvidamente G. Picon sobre Balzac. E toda a obra balzaquiana lhe parece passível dessa releitura do Génesis: a narrativa de um homem que quer ser Deus sendo Adão, civilizando-se, urbanizando-se, ainda que para tal tenha de abandonar o jardim, comendo o fruto da árvore proibida, construindo ainda mais uma volta da torre de Babel, o agricultor Caim matando o pastor Abel, ambos fruto do mesmo 
ventre (Picon, 1969: 112-6, 120 et passim). Coexistiria em Balzac a tentação do paraíso permitido e a do fruto proibido, a exaltação do amor mortalmente excessivo e "esse gosto convencional do amor debaixo dos caramanchões batidos pelo luar, onde Montherlant poderia, com toda a justiça, descobrir uma alma de 'costureirinha'” (Picon, 1969: 113). Também em Garrett facilmente se encontraria essa costureirinha, ser comum e imprevisível, sempre jovem, sempre deslocada. Comentaria Herculano, ao descobrir que eram de Garrett os poemas das Folhas Caídas: “...Parece que tem vinte anos!”.

Luo delicia-se a ver o corpo da Costureirinha mergulhar nas águas límpidas de uma cascata, até ao momento em que ela é mordida por uma serpente e toma consciência do jogo: "Tu me trouves sûrement aussi idiote qu'un chien qui court pour chercher l'os qu'on a lancé. Je ne suis pas une de ces jeunes filles françaises de Balzac. Je suis une fille de la montagne" (Sijie, 2000: 179). Na verdade, tal criador sabe, ab initium, que o Paraíso não pode existir sem que a criatura dele saia um dia. A morte do pai de Chimène é somente o pretexto para que Chimène prove o carácter sublime e sublimado do seu amor, anunciado logo nas primeiras falas: "ma gloire et mon amour ont pour moi tant d'appas/ Que je meurs s'il s'achève ou ne s'achève pas" (Corneille, 1976: 24). Em Balzac, entre vários Rastignacs que trocam o paraíso da Província pelo inferno de Paris, são recorrentes os malogrados êxitos, as posses ilusórias dos que sobem na vida. La Peau de Chagrin é a representação do desejo da criatura demiúrgica: encolhe à medida que se cumprem os desejos. Garrett-amante confessa a Rosa Montufar: "Sempre me persuadi que a posse matava o amor no homem, e daí por necessária reflexão, morria o da mulher" (Garrett, 2007: 89). Garrett-romancista faz com que o narrador saiba, da boca de Frei Dinis, do êxito social de Carlos, que se fez barão, sucedâneo dos frades, "ruim substituição", conclui (Garrett, 2010: 459). Garrett-dramaturgo exibe no palco esse "pecado de orgulho", de que fala Omescu, "quando procura afirmar-se como réplica do mundo, não só porque contesta a unicidade deste, mas ousadamente lhe nega a excelência” (Barata, 1992: 26). Mas também Garrett-educador vive o idêntico paradoxo que é educar, conduzir a criança para a felicidade possível, infligindo-lhe castigo, dor e disciplina em doses suportáveis. Se possuir mata o Criador, não possuir, mata a Criatura: entre ambos os revezes se moverá sempre o amante, o romancista, o mestre. 
Para a alma e para o corpo é desgraçadamente um veneno a experiência do mundo, mas é forçoso - ainda mal! - tomar-se este veneno; e para que não venha de golpe, tal que mate e arruíne de uma vez, dê-se em doses progressivas - acostume-se a ele o estômago com a receita de Mitríades (Garrett, 2009: 110).

De uma forma ou de outra, a obra de Garrett está marcada por esta imagem do Paraíso perdido, local em que a criatura ambicionou tornar-se Deus, cumprindo o destino de ter sido feita à imagem e semelhança de Deus. Se Garrett admira em Rousseau a intenção pedagógica, cedo se apercebe nele da contradição que é a educação do bom selvagem: Emílio é "um dos melhores e dos peiores [sic] livros jamais escritos" (Garrett, 2009: 172). Rousseau, cioso da bondade natural do selvagem, temia o livro de uma forma contraditória: não queria que as mulheres estudassem, ainda que gostasse que elas o lessem; transportara os livros em caixotes para o desterro do lago Bienne, mas disse que nunca os abrira (talvez porque os já tinha lido...). Pelo contrário, ainda que nem sempre de uma forma explícita, Garrett pouco confia na bondade dos selvagens: "A humilde cabana do pastor não se deve fechar mais às bênçãos da educação intelectual do que o palácio" (Garrett, 2009: 116). É certo que só se deve ensinar o que para a vida social é preciso (e o que é preciso ao pastor não é o que é preciso ao parlamentar). Mas "a órbita" do que se deve saber "se vai estendendo em âmbito, e alargando como as linhas da parábola até ao infinito" (Ibidem). Ainda que não queira a filha "para doutora" (Garrett, s.d.: I, 1463), ou não veja a necessidade das mulheres se aplicarem a estudos em que não possam dar utilidade pela sua função de naturais educadoras (Garrett, 2009: 191 ss., Carta IX, passim), Garrett lembra com orgulho a mãe que "lia, sabia, prezava as coisas de arte; mas não falava em livros senão connosco. [...] Governava a sua casa, cosia os filhos [sic], ensinava-os de palavra e de exemplo" (Garrett, s.d.: II, 1788). No que diz respeito às capacidades intelectuais, "tirando a circunstância da gravidação, e todas as consequências que acompanham a maternidade [...], a mulher fica perfeitamente igual ao homem" (Garrett, 2009: 193), e, caso seja Rainha, governante de um povo, "deve ser a sua educação intelectual a de varão e não de mulher" (Ibid: 215). Por isso há nos protagonistas, ainda que predominantemente nos masculinos, sempre qualquer coisa de Adão orgulhoso, e até feliz, ainda quando a ambição divina implicou a expulsão do Paraíso. Porque o Adão Social, à semelhança do Adão 
Natural, vive igualmente num "Éden fantástico de sua criação", construído agora pelos homens, no qual a serpente arremeda as palavras de Deus:

De nenhuma árvore da horta comendo comerás; Porém da árvore da ciência do bem e do mal, dela só comerás se quiseres viver. (Garrett, 2010: 280)

A tentação do Adão Social é pois inversa, sobretudo numa personagem como Carlos, pois "Poucos filhos do Adão social tinham tantas reminiscências da outra pátria mais antiga, e tendiam tanto a aproximar-se do primitivo tipo que saíra das mãos do Eterno". Forceja ele por "sacudir de si o pesado aperto das contrições sociais, e regenerar-se na santa liberdade da natureza” (Garrett, 2010: 281). Aspira pois ele, o Adão Social, a comer de todas as árvores da horta, tudo deglutir, e a nada dizer que não, dispersando-se: é a sua estrela, o seu destino de criatura. Mas sempre acabando por recusar a norma-fixa do Paraíso, que, neste novo contexto, obriga a morrer serenamente da "indigestão de ciência". Para não ser vítima do indiferentismo, sentimento tão próprio dos paraísos, teria de cair noutra tentação, e ser agora expulso do Éden social. O que não vem a suceder com Carlos, nas Viagens:

[...] caiu no indiferentismo absoluto, que se fez o que chamam céptico, que lhe morreu o coração para todo o afecto generoso, e que deu em homem político ou em agiota.

- Pode ser.

- Mas qual das duas foi, deputado ou barão? queremos saber.

- Saberão.

- Queremos já.

- E se fossem ambas?

- Oh, horror, horror, maldição, inferno! Ferros em brasa, demónios pretos, vermelhos, azuis, de todas as cores! Aqui sim que toda a artilharia grossa do romantismo deve cair em massa sobre esse monstro, esse...

- Esse quê? Pois em se acabando o coração à gente...

- Eu não creio nisso. Acaba-se lá o coração a ninguém!...

(Garrett, 2010: 364-5) 
Leitor de Lucrécio e Goethe, o que Garrett contesta é afinal a perceção de um mundo estático, canónico, feito de muitas normas e tabus, avesso ao imanente hibridismo da natureza, ignorante da dialética e simpatia dos átomos, servil, quer à "doxa" dos interesses coletivos, quer ao solipsismo dos êxtases individuais: "Não penses [...] que haja coisas na Natureza que belas não sejam. Todas o são..." (cf. Monteiro, 1971, I: 329). Na verdade, os ditos paraísos, naturais ou sociais, estão todos viciados por Deus:

Natural ou social-absoluto é a mesma coisa. Podemos abstrair o homem do estado social-relativo ou positivo, e considerá-lo no social-absoluto, ou no natural nesse sentido: mas abstrair para um estado pretendido natural que é contra a natureza do homem, ao homem essencialmente social considerá-lo abstractamente da sociedade - é teoria inútil e que pode ser perigosa. (Garrett, 2009: 176n)

Paraísos absolutos, perfeitos, acabados e irrevogáveis, não existem:

Hoje o mundo é uma vasta Barataria, em que domina el-rei Sancho. Depois há-de vir D. Quixote. O senso comum virá para o milénio: reinado dos filhos de Deus! Está prometido nas divinas promessas... como el-rei da Prússia prometeu uma constituição; e que não faltou ainda, porque... porque o contrato não tem dia; prometeu, mas não disse para quando. (Garrett, 2010: 101)

O único paraíso viável é o da dialética: e esse tem de ser por nós construído. Também por isso, nas Viagens e nos prefácios, vem regularmente à baila a problemática definição do Romantismo, que não deve ser, cremos, entendido como conceito cronológico, identificável somente com "o tempo de Garrett", a primeira metade do século xix. Ele é muito mais interessante se visto como uma tipologia do excesso do Adão Social, ainda que seja necessário o enquadramento histórico para bem o entender. Excesso do Adão Social, arma de arremesso contra outro excesso, o do Adão Natural. Pois também o excesso do Adão Natural não tem lugar na Natureza: não há Éden terreal, nem bons selvagens, e são muito suspeitos os "amáveis salteadores" ou os "elegantes facinorosos". O que não impede que o Romantismo possa ser definido pela "doxa", a radical opinião dominante, que determina o que é "um verdadeiro escritor 
romântico", que busca estereótipos, "figurinos", moldes picotados, confundindo o modo com a moda...

Por quantas maldições e infernos adornam o estilo dum verdadeiro escritor romântico, digam-me, digam-me: onde estão os arvoredos fechados, os sítios medonhos desta espessura. Pois isto é possível, pois o pinhal da Azambuja é isto?... Eu que os trazia prontos e recortados para os colocar aqui todos os amáveis salteadores de Schiller, e os elegantes facinorosos do Auberge-des-Adrets, eu hei-de perder os meus chefes-de-obra! Que é perdê-los isto - não ter onde os pôr!... (Garrett, 2010: 119-120)

Moldes recortados em papel, tarefa de alfaiate: "De certo modo não podemos deixar de nos vestir - do nascimento à sepultura, somos joguete nas mãos do alfaiate, e quem diz homem civilizado diz naturalmente homem que paga a sua contribuição ao costureiro", comenta Cruz Malpique sobre o dandismo de Garrett (Malpique, 1954: 104). As palavras, as frases, também são fatos. Mas se a vida nos impõe conceitos, nada nos impede de os tornar simultaneamente comuns e estranhos, lugares-comuns e lugares-próprios, clichés mais distingués. Revelava o Conde de Arnoso que "Nunca, em cada manhã, Garrett deixou de previamente combinar, sábia e artisticamente, a composição do seu vestuário, como um pintor que pacientemente prepara a sua paleta”. Afiançava Balzac que o homem que na moda nada mais vê que a moda, não passa de um tolo. Vestir-se com arte é sinal de uma urbanidade que passa a ser expressão da individualidade, um gosto intermédio de ser diferente como toda a gente: "Cobre-se o bruto, paramentam-se o rico e o parvo, só o homem elegante se veste" (Balzac, apud Malpique, 1954: 113 para ambas as citações). Há muitas formas de usar o molde. No livro de Dai Sijie, o velho alfaiate chinês que ouve a história de Edmond Dantés introduz no molde "quelques fantaisies, discrètes et spontanées", imprevisíveis:

Dumas lui-même eût été le premier surpris, s'il avait vu nos montagnardes moulées dans des sortes de vareuses à épaules tombantes et à grand col, carré en arrière et pointu en avant, qui claquait dans le vent. Elles sentaient presque l'odeur de la Méditerranée. (Sijie, 2000: 158) 
A decorrente indeterminação do que é o Romantismo está também presente na obra de Dai Sijie, ainda que representada por longínquos leitores chineses, que dele só têm contacto pelas leituras clandestinas de Cervantes, Balzac, Alexandre Dumas Pai, Flaubert, Romain Rolland... Mas nem na China se encontra Romantismo unívoco. Significativamente, o que Binoclard, o Caixa de Óculos, filho de poetas encartados, entende por Romantismo ("des paroles positives, teintées de romantisme realiste", textos de intervenção social), não é compatível com o que Ma e Luo, sem instrução canónica, compreendem como tal. Ma e Lou só sabem o que do Romantismo lhes parece dizer Balzac e Flaubert: "L'émotion et l'amour" (Sijie, 2000: 92). E, estando tais temas censurados no Livro Vermelho de Mao, os buscam eles no povo, nos relatos orais, nos enigmas em verso de um eremita da montanha. Mas também aí o velho versejador pergunta, quando lho pedem:

- C'est quoi ça, le romantisme? (Sijie, 2000: 92)

E apenas lhes devolve um enigma brejeiro sobre o medo que provoca o amor:

Dis-moi/ Un vieux pou,/ Il y a peur de quoi?/ Il a peur de l'eau qui bout,/ De l'eau qui bout./ Et la jeune nonne,/ Dis-moi,/ Elle a peur de quoi?/ Elle a peur du vieux moine/ Rien d'autre/ Que du vieux moine.

Ninguém obtém o romantismo que procura. Por isso tem ele de ser talhado à medida. Para o tornar legível, Caixa de Óculos cede à tentação de o adaptar ao órgão oficial do partido: "Dites-moi/ Les petits poux bourgeois,/ Ils ont peur de quoi?/ De la vague bouillante du prolétariat" (Sijie, 2000: 99).

No início do mundo, talvez todos os géneros se tenham confundido, tal como suspeitavam os românticos quando falavam de hibridismo. Na narrativa de Sijie, a classificação do género é dificultada pela imbricação das formas usadas: o conto de fadas, o romance autobiográfico, a narrativa popular, a novela polifónica, a parábola, a tragédia, o romance iniciático (Plaquette, 2008: 35-37, passim). Perante a fortaleza do dogma, o modo literário ressente-se invariavelmente da ambivalência dos géneros. Há passagens de Garrett (leia-se, v.g., O Arco de Sant'Ana) que misturam poesia e prosa, ou narrativa e drama, e mais parecem escritas para uma crónica ou para um texto teatral (cf. Garrett, 2004: 72-82). "Trata-se de um 
romance, de um drama”, dirá ele das Viagens (Garrett, 2010: 120). Mas não só a designação do género lhe foge. Em Garrett, também o conceito de "Romantismo" é anfibológico, variando com a audiência ou, talvez mais exatamente, com o emissor. Encontra-se na recolha do Romanceiro, que começou nas histórias que ouviu na infância, da boca de Rosa Lima ou da de Brígida. Mas acaba por se tornar para Garrett um sinónimo do sublime, de um "je ne sais quoi", que mais se assemelha a uma corda de violino que permanentemente se tem de adaptar à temperatura e humidade ambiente. Beleza feita de silêncio, grandiosidade, pedanteria, simetria de cálculo, heresia e dogma, do emissor ou do recetor. O Género, tal como a Beleza que ele visa, não é nunca qualidade do objeto, mas resultado da relação entre nós e ele (cf. Monteiro, 1971: I, 313):

Fora de Vila é um vasto largo, irregular e caprichoso como um poema romântico; ao primeiro aspecto, àquela hora tardia e de pouca luz, é de um efeito admirável e sublime. Palácios, conventos, igrejas ocupam gravemente e tristemente os seus antigos lugares, enfileirados sem ordem aos lados daquela imensa praça, em que a vista dos olhos não acha simetria alguma; mas sente-se na alma. É como o ritmo e medição dos grandes versos bíblicos que se não cadenceiam por pés nem por sílabas, mas caem certos no espírito e na audição interior com uma regularidade admirável (Garrett, 2010: 308).

A simetria que se sente na alma, os versos que caem certos no espirito... Este mundo edénico é quase sempre o teorizado por Crátilo: o som imita o objeto, a imagem evoca-o, invoca-o, convoca-o. O poeta sonha amiúde com Orfeu. Ao som da sua lira, conduzirá animais e homens. No limite, a representação da escrita é sempre uma superstição, uma fórmula de feiticeiro que fabrica um mundo imaginário, fazendo-o passar por real, tornando-o mais real que a própria realidade, que é demasiado fugaz: os versos da curandeira afastam a doença, as palavras do contador de histórias convocam a felicidade de amar (Sijie, 2000: 13, 49, 53). A tradução, a boa tradução, não deixa de o explorar, desenhando sonoridades e sentidos imprevistos: "Ba-er-za-ke. Traduit en chinois, le nom de l'auteur français formait un mot de quatre idéogrammes. Quelle magie que la traduction!” (Sijie, 2000: 71, cf. 138).

Não será por acaso que os protagonistas veem a literatura como um prolongamento dos melodramas norte-coreanos que passam por vezes no cinema: 
fascina-os o primeiro dos mistérios da arte. Com a arte aprendem a fazer chorar, a fazer amar, a curar, a magoar. O Melodrama ensina-lhes a comover, a mover, ainda que duma forma desprevenida, que apanha o leitor por onde ele não montou guarda: "Il faut juste les maintenir éveillées..." (Sijie, 2000: 54). Não será também por acaso que o narrador é Ma, violinista que aprende ao longo do romance a ser escritor. Se a força do melodrama é devastadora, é preciso aprender a dominá-la. Daí os progressivos cuidados do narrador com a disciplina, a contenção, a litote, os ritmos, a ordem das frases, a alternância de vozes, o silêncio forçado e a ocultação de informação: “... la première phrase, la plus difficile, la plus délicate; je voulais quelque chose de sobre" (cf. Sijie, 154, mas também 49, 54-56, 102, 104, 123). Recordamos aqui a surpresa de Proust, quando Victor Hugo lhe falava de Horácio, Ovídio, Regnard, Molière...

Quase poderíamos dizer, renovando talvez, por esta interpretação, aliás muito parcial, a velha distinção entre clássicos e românticos, que são os públicos (os públicos inteligentes, entenda-se) que são românticos, enquanto que os mestres (mesmo os mestres preferidos dos públicos românticos) são clássicos. (Proust, 1991: 63)

Não cremos ter sido ainda bem entendida a semelhante atração que Garrett tem pelo melodrama, até porque nos deixamos enganar pelas suas frequentes ironias face ao género: os repetidos "Oh horror, horror, maldição, inferno! Ferros em brasa, demónios pretos, vermelhos, azuis, de todas as cores! Aqui sim, que toda a artilharia grossa do romantismo deve cair em massa sobre esse monstro, esse..." (Garrett, 2010: 365). Mas há na comoção dos dramas de Garrett uma inegável aprendizagem dessa força, que ele espera tornar subtil e precisa. Teriam sido determinantes na sua formação as opiniões de Frei Alexandre da Sagrada Família, sem dúvida em consonância com as de um autor que traduziu. Para este, a eloquência é, antes de mais, o "talento de fazer nas almas dos outros, pelo uso da palavra, a impressão do sentimento ou movimento que pretendemos" (apud Monteiro, 2007: 121 ou, mais abrangentemente, Monteiro, 1974: 161 et passim). Mas um dos primeiros sinais talvez seja a sua precoce paixão pela obra de Eurípides, que estudou desde a adolescência (Monteiro, 1971: I, 87). Burilará desde os primeiros anos a linguagem emocional e a sua estilística (cf. Monteiro, 
1971: I, 418). Um bom exemplo do Melodrama é sem dúvida Frei Luís de Sousa, já com depurada técnica. Num autor como Garrett, é ainda evidente a passagem do significado setecentista do Melodrama, radicado na ópera (o melodrama é essencialmente drama em música), para o significado oitocentista do conceito (quando o melodrama se torna drama sem música, centrado na linguagem exclamativa e na perturbação emotiva da audiência). Interessa para esta questão recuperar a intenção primeira do Melodrama: criar Orfeus, mover homens. Garrett é um homem teatral, mas sobretudo um homem de teatro ("tudo se resume a essa mania"): sabe por isso que não pode prender por muito tempo um espetador à cadeira, que só o pode prender "no momento mesmo". E, se quer instruir o povo, sempre terá de o apanhar pela simplicidade da emoção. É nesse mesmo sentido que o Melodrama interessara antes Diderot, concebendo, quer o paradoxo do actor quer o homem de génio, entre o excesso de sensibilidade e o distanciamento mimético (cf. Monteiro, 1985: 80). E também por isso interessará o Melodrama a Peter Brooks, quando nele estuda a excitação excessiva dos sentidos e dos sentimentos visada pelo teatro e pela literatura, ainda quando falamos de romancistas como Balzac, notáveis pelo seu "realismo". (Brooks, 1995: max. 110-152). A "capacidade simbiótica” de Balzac tanto está patente nas considerações de uma gata inglesa (Monteiro: 2003: 430), como na capacidade emotiva de uma linguagem natural de que nos fala Herder (1987: 37). O Melodrama faz ao significante o que o Mito faz ao significado: exagera para tornar percetível, configura para universalizar...

O livro de Sijie termina com um auto-da-fé dos livros que deram vida à Costureirinha. Aquecemo-nos a esse fogo. Construímos pontes entre os melodramas do Adão Natural e os circunlóquios académicos do Adão Social... Criamos a possibilidade de um estado intermédio quando ousarmos tocar no fruto proibido, escrever sobre o que se não escreveu ainda. Mas o problema da Arte é criar paraísos artificiais: aquilo sobre que escrevemos é sempre mais do que a escrita... Sem dúvida é isto uma fábula... Mas as fábulas "inventou-as a abnóxia servidão; inventou-as o servilismo do escravo para não desprazer ao devasso orgulho do senhor" (Garrett, 2009: 162).

Talvez tudo isto não passe de um mito, "palavra grega, e de moda germânica, que se mete hoje em tudo e com que se explica tudo... quando se não sabe explicar" (Garrett, 2010: 99)... 


\section{BIBLIOGRAFIA}

AMORIM, F. Gomes de (1881-1884), Garrett. Memórias Biographicas, 3 vols., Lisboa, Imp. Nacional

BAlZAC, H. de (1831), La Peau de Chagrin, Roman Philosophique, Paris, Ch. Gosselin, Urbain Canel

, (1975), Le Père Goriot, Paris, Le Livre de Poche

(1968), Ursule Mirouët, Paris, Le Livre de Poche

BARATA, José Oliveira (1979), Didáctica do Teatro: uma Introdução, Coimbra, Almedina (1992), "Máquina do Mundo" e Poesia Única..., in "Poesia da Ciência. Ciência da Poesia", ed. Ofélia Paiva Monteiro, Lisboa, Escher, pp. 25-33

BARTHES, Roland (1973), Le Plaisir du Texte, Paris, Seuil

BRAGA, Theophilo (1903), Garrett e o Romantismo, Porto, Liv. Chardron

BROOKS, Peter (1995), The Melodramatic Imagination. Balzac, Henry James, Melodrama, and the Mode of Excess, 2.nd edition with new preface, New Haven/ London, Yale University Press

CORNEILlE, Pierre (1976), Le Cid, introd. Y. Brunsvick et P. Ginestier, Paris, Didier

DANTE (s.d.), La Divina Commedia, Project Gutenberg, Disponével online em: http://www.gutenberg.org/browse/authors/d\#a507

FERreirA, Alberto (s.d.), Perspectiva do Romantismo Português, $4^{\mathrm{a}}$ ed., Lisboa/ Porto, Litexa Editora

GARRETT, Almeida (2004), O Arco de Sant'Ana, ed. Maria Helena Santana, coord. Ofélia Paiva Monteiro, Lisboa, IN-CM

, (2007), Cartas de Amor à Viscondessa da Luz, ed. Sérgio Nazar David, apres. Ofélia Paiva Monteiro, Vila Nova de Famalicão, Quasi

, (2009), Da Educação, ed. Fernando Augusto Machado, Edição Crítica das Obras de Almeida Garrett, coord. Ofélia Paiva Monteiro, Lisboa, IN-CM

, (2010), Viagens na Minha Terra, ed. Ofélia Paiva Monteiro, Lisboa, IN-CM

, (s.d.), Obras de..., 2 vols., Porto, Lello \& Irmão Editores

HERDER (1987), Ensaio sobre a Origem da Linguagem, trad. José M. Justo, Lisboa, Antígona

JOURDAIN, Pierre (1992), De la Poésie comme Antidépresseur, in "Poesia da Ciência. Ciência da Poesia”, ed. Ofélia Paiva Monteiro, Lisboa, Escher, pp. 101-108

LAMBOTTE, Marie-Claude (1984), Esthétique de la Mélancolie, Paris, Aubier

MONTEIRO, Ofélia Paiva (1985), La Pensée Esthétique de Diderot, in "Confluências", n. ${ }^{\circ}$ 1, Coimbra, Janeiro, pp. $75-84$

(1962), No Alvorecer do "Iluminismo" em Portugal: D. Francisco Xavier de Meneses, $4 .^{\circ}$ Conde da Ericeira (I), in "Revista de História Literária de Portugal", Coimbra, FLUC, Ano I, Vol. I, pp. 191-233

(1974), D. Frei Alexandre da Sagrada Família. A sua Espiritualidade e a sua Poética, Coimbra, Universidade de Coimbra 
(1971), A Formação de Almeida Garrett. Experiência e Criação, 2 vols., Coimbra, Centro de Estudos Românicos

(2003), Bichos e Homens: Balzac e a sua Gata Inglesa, Sep. "Cartographies. Mélanges offerts à Maria Alzira Seixo, [Número temático de] 'Ariane. Revue d'Etudes Littéraires Françaises", Lisboa, pp. 429- 444

, (2006), Almeida Garrett. 150 Anos Depois, "Discursos", n. . 1, VI Série, Lisboa, Universidade Aberta, pp. 19-30

, (2007), Bocage e Filinto: Confluências e Dissonâncias, in "Leituras de Bocage", ed.

M. Luísa Malato Borralho, Porto, NEL/FLUP, pp. 119-131

, (2011), Entre Luzes e Romantismo. A estética hedonista do Liceu das Damas, de Garrett, e a reflexão sobre 'poesia' que propõe, in "Revista de Estudos Literários", n. ${ }^{\circ}$, Coimbra, CLP/ FLUC, pp. 195-249

OVIDIO (1991), Las Metamorfosis, introd. F. Montes de Oca, Mexico, Editorial Porrúa

PICON, Gaëtan (1969), Balzac por ele próprio, trad. Daniel Gonçalves, Lisboa, Portugália Editora

PLAQUETTE, Aude (2008), Etude sur Balzac et la Petite Tailleuse Chinoise, Paris, Ellipses

PROUST, Marcel (1991), Sobre a Leitura, trad. José Augusto Mourão, Lisboa, Vega

SIJIE, Die (2000), Balzac et la Petite Tailleuse Chinoise, Paris, Gallimard. Existe edição portuguesa, também de 2000: Balzac e a Costureirinha Chinesa, trad. Maria Filomena Duarte, Lisboa, Terramar. Dai Sijie é igualmente o realizador da versão cinematográfica, que circulou em Portugal com um título mais aristocrático: Balzac e a Princesa Chinesa, (TF1/ Le Film, França, 2002), DVD/ Portugal, 2004

STEINER, George (2005), As Lições dos Mestres, trad. Rui Pires Cabral, 2. a ed., Lisboa, Gradiva 